\title{
Long-term trends in juvenile flatfish indicate a dramatic reduction in nursery function of the Balgzand intertidal, Dutch Wadden Sea
}

\author{
Henk W. van der $\operatorname{Veer}^{1, *}$, Joris $\operatorname{Koot}^{1}{ }^{1}$ Geert Aarts $^{1,2}{ }^{\text {, }}$,ob Dekker ${ }^{1}$, \\ Willem Diderich ${ }^{1,2}$, Vânia Freitas ${ }^{1,3}$, Johannes IJ. Witte ${ }^{1}$ \\ ${ }^{1}$ Royal Netherlands Institute for Sea Research (NIOZ), PO Box 59, 1790 AB Den Burg Texel, The Netherlands \\ ${ }^{2}$ Wageningen IMARES (Institute for Marine Resources and Ecosystem Studies), PO Box 68, 1970 AB IJmuiden, \\ The Netherlands \\ ${ }^{3}$ CIMAR/CIIMAR - Centro Interdisciplinar de Investigação Marinha e Ambiental, Universidade do Porto, \\ Rua dos Bragas 289, 4050-123 Porto, Portugal
}

\begin{abstract}
Since 1975, juvenile flatfish (plaice and flounder) populations have been monitored at the Balgzand intertidal and, based on this data series (1975-2007), the interannual patterns in predation pressure were quantified. Temporal patterns in abundance have changed greatly, especially for plaice. Up to the early 1980s, 3 year classes (0-, I- and II-group) were present and growing up in the area, but from the late 1980s onwards, densities of the I- and II-group plaice dropped from a few hundred individuals per $1000 \mathrm{~m}^{2}$ to levels close to zero. It appears that the Balgzand intertidal has lost its nursery function for I- and II-group plaice, although feeding conditions have remained the same or even slightly increased since the late 1970s. The absence of I- and II-group flatfish in the intertidal cannot be explained at present; however, processes operating offshore are most likely involved. As a consequence, the annual predation pressure by juvenile flatfish upon the intertidal macrozoobenthos dropped by $94 \%$, declining from an average of approximately 5 to $0.25 \mathrm{~g}$ ash free dry mass $\mathrm{m}^{-2}$. Such a decline in top-down predation may not only have directly influenced the macrozoobenthic community, but may also have indirectly affected food availability and accessibility for other top predators (e.g. shorebirds).
\end{abstract}

KEY WORDS: Predation · Plaice $\cdot$ Flounder $\cdot$ Pleuronectes platessa $\cdot$ Platichthys flesus $\cdot$ Wadden Sea Benthos-fish interaction $\cdot$ Top-down control $\cdot$ Nursery function

\section{INTRODUCTION}

Intertidal benthic systems are often subject to strong fluctuations in abiotic conditions because of the combination of seasonal and daily variability in salinity and temperature between emersion and submersion. As a consequence, species richness of the macrobenthic infauna in these systems is relatively low; however, those species present often occur in high densities and biomasses (for overview, see Goodall 1983), attracting large numbers of predators. Predation in the intertidal occurs almost continuously, alternating between mobile epibenthic species during immersion and wading birds during exposure of the flats. Predator-prey interactions in intertidal systems are complex (Freitas et al. 2008). Among the infauna, some polychaete worms are dominant opportunistic consumers, preying on other worms and crustaceans (Meire et al. 1994). Wading birds prey on a wide range of benthic organisms, especially bivalves and polychaetes, and thus their food supply is restricted by aspects such as accessibility (depth), digestibility (size) and profitability (energy content) (Zwarts et al. 1992). The most abundant mobile epibenthic species include opportunistic feed- 
ers such as crustaceans (the shore crab Carcinus maenas and the brown shrimp Crangon crangon) and various gobies and juvenile flatfish species.

The top-down effects of predation on the macrozoobenthic community are not clear. In general, macrozoobenthic biomass in temperate estuaries appears to be controlled bottom-up by primary production (Herman et al. 1999). However, top-down effects of predators can strongly influence species composition. For example, predation by Carcinus maenas can significantly reduce the numbers of the polychaete worm Manayunkia aestuarina on mudflats (McLusky 1989), and crustaceans can reduce the population of the amphipod Corophium volutator by over 50\% (Pihl 1985). In terms of energy flow, gobies and crustaceans represent by far the highest predation pressure; apart from infauna, this also includes predation on other epibenthic species and substantial cannibalism on egg and juvenile stages. Predation by juvenile flatfish is linked more closely with macrozoobenthic prey items, with sole Solea solea feeding almost exclusively on polychaetes, and plaice Pleuronectes platessa and flounder Platichthys flesus feeding also on juvenile bivalve spat (Kuipers 1977, De Vlas 1979a, Summers 1980, Amara et al. 2001, Rijnsdorp \& Vingerhoed 2001). Juvenile flatfish feed not only on whole prey items but also, to a large extent, on regenerating body parts such as the siphon tips of bivalves and the tail tips of lugworms (Kuipers 1977, Ansell et al. 1999). This may directly or indirectly influence the survival of their prey; predation on tail tips of lugworms affects and reduces longevity (Bergman et al. 1988) and predation on siphon tips forces bivalves to reduce burying depth, thereby increasing the risk of being eaten by probing predators such as shorebirds (De Goeij et al. 2001).

In the Balgzand area, a large intertidal ecosystem in the western Dutch Wadden Sea, juvenile plaice and flounder are the most abundant flatfish species, with dab Limanda limanda and sole occurring only incidentally (Bolle et al. 1994, van der Veer et al. 2001). Predation on macrozoobenthos by juvenile plaice and flounder was estimated to be approximately $6 \mathrm{~g}$ ash-free dry mass (AFDM) $\mathrm{m}^{-2}$ (De Vlas 1979a), corresponding to one-third of the total predation pressure (Kuipers et al. 1981). Such predation might significantly affect macrozoobenthic species composition and abundance. These calculations were done a few decades ago in the late 1970s by Kuipers (1977) and De Vlas (1979a) but, since then, significant changes for the Wadden Sea area have been recorded. Regime shifts at multi-trophic levels have been described for 1979 and 1988 and perhaps also for 1998 (Weijerman et al. 2005). For plaice, an offshore shift in the distribution of juveniles to deeper waters in the 1990s (van Keeken et al. 2007) and a decrease of densities of II- and I-group plaice in the deeper subtidal parts of the Dutch Wadden Sea (Tulp et al. 2008) has taken place. However, it is currently unknown to what extent this also applies to the intertidal area and how it affects predation pressure on the macrozoobenthos community.

The present study relies on 2 data sets in the western Dutch Wadden Sea: the NIOZ fyke net programme, during which daily catches of fish fauna were registered from 1960 onwards, and the NIOZ Balgzand high-water programme, carried out between 1975 and 2007, which quantitatively monitored the seasonal patterns in intertidal mobile epibenthic fauna. These longterm time series allow us to follow the temporal patterns in abundance and predation pressure by juvenile plaice and flounder on the Balgzand intertidal macrobenthos. In combination with information from stomach contents and prey abundance (intertidal macrozoobenthos), these data sets provide a basis for: (1) quantifying changes in the abundance and predation pressure of juvenile plaice and flounder over time; and (2) determining whether possible top-down effects of predation by juvenile plaice and flounder still affect the Balgzand macrozoobenthic community.

\section{MATERIALS AND METHODS}

Flatfish sampling. The temporal patterns in juvenile plaice and flounder abundance in the western Wadden Sea were analysed from the NIOZ fyke net programme. Trends in annual predation pressure on intertidal macrobenthos was determined for a large $\left(50 \mathrm{~km}^{2}\right)$ intertidal area in the western Wadden Sea from the NIOZ Balgzand high-water programme.

NIOZ fyke net programme: Passive fishing was set up near the southern part of Texel, de Hors, at the entrance of the Dutch Wadden Sea (Fig. 1). Fishing was done with a passive trap, known as a 'kom-fyke' (Nédélec 1982), which consists of a pound net and a fyke supported by wooden poles and with a leader of $200 \mathrm{~m}$ running from above the high water mark into the subtidal. At the end, 2 chambers catch and retain fish and other species (see Fig. 1 in van der Veer et al. 1992). The stretched mesh size of the leader and the 2 chambers is $20 \mathrm{~mm}$. The semidiurnal lunar tide is the dominant component and tidal range varies between 1 and $2 \mathrm{~m}$ depending on conditions (neap versus spring tide, day versus night, wind stress and direction). Normally, tidal current velocity in the fishing area does not exceed $1 \mathrm{~m} \mathrm{~s}^{-1}$, except for periods with strong wind stress. Fishing with the kom-fyke started in 1960 and has been run ever since in spring (April-June) and autumn (September-October). Usually, the kom-fyke is emptied every morning from Monday to Friday irrespectively of tidal phase, except on occasions of bad 


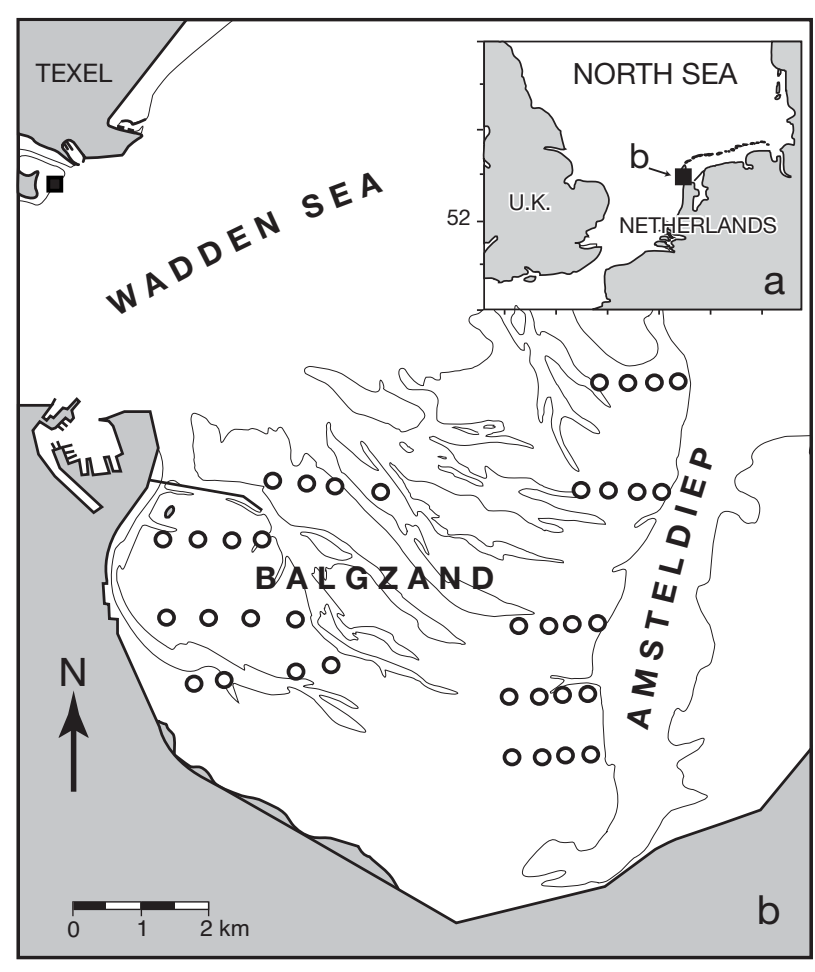

Fig. 1. The Balgzand intertidal in the western Dutch Wadden Sea. Location of NIOZ fyke net near the southern tip of Texel is indicated ( ). Flatfish sampling was based on 9 transects, each consisting of 4 hauls (open circles). Thin lines indicate the low water mark, thick lines the high water mark

weather conditions. When catches are low, the net is emptied every other morning.

For the present study, catches from 1975-2009 were analysed. All catches were sorted immediately down to species level and individuals were measured to the nearest $\mathrm{cm}$ in total length. Age estimation of juvenile plaice and flounder was based on size. In case of doubt, individual age was verified by means of otolith reading. The mean number of individuals caught in autumn catches was taken as an index for the different age classes in the Wadden Sea and represents a mixture of the intertidal and subtidal flatfish populations present in the western Wadden Sea.

NIOZ Balgzand high-water programme: Over the period 1975 to 2007, the Balgzand intertidal was sampled at frequent intervals (2 to $4 \mathrm{wk}$ ) from February until (in most years) October during the daytime. During most surveys, all 36 fixed stations distributed over Balgzand (Fig. 1) were sampled within a $3 \mathrm{~h}$ period around high tide, during which the flatfish population is randomly distributed over the area (Kuipers 1977). Fishing was done from a rubber dinghy with a $25 \mathrm{HP}$ outboard motor at a speed of approximately $35 \mathrm{~m} \mathrm{~min}^{-1}$ (Riley \& Corlett 1966) using a $1.9 \mathrm{~m}$ beam trawl with 1 tickler chain and a net mesh size of $5 \times 5 \mathrm{~mm}$. Water tempera- ture was measured during each survey. The start positions of the hauls were indicated by wooden poles at the beginning of each transect, and determined by GPS in more recent years. The length of each haul was assessed with a meter wheel fitted to the trawl.

Catches were stored in $4 \%$ formaline (until 1990) or deep-frozen (from 1991 onwards) and all species were sorted within a few days. All juvenile plaice and flounder were measured and divided into $0.5 \mathrm{~cm}$ total length classes, except in 1979 and 1982 when only 0-group juveniles were analysed. The number of plaice caught was corrected for size-selective mesh (Dapper 1978) and catch efficiency (Kuipers 1975) and converted into individuals per $1000 \mathrm{~m}^{2}$ (ind. $\left[10^{3} \mathrm{~m}^{2}\right]^{-1}$ ). For flounder, similar efficiencies as for plaice were assumed. Subsequently, catches were split into age classes according to length. In case of doubt, individual age was verified by means of otolith reading. The arithmetic mean of all stations sampled during a survey was calculated and considered to reflect the total mean density at Balgzand (cf. Zijlstra et al. 1982, van der Veer 1986, van der Veer \& Witte 1999).

Estimation of predation pressure. Daily food intake was estimated for each survey for 0-, I- and II-group plaice and flounder separately, based on specific energy requirements following De Vlas (1979a) with some slight modifications. Energy requirements consisted of 2 components: (1) contribution for metabolism (daily maintenance) and (2) contribution for observed growth. Energy required for locomotion and other expenditures was considered to be negligible in juvenile plaice and flounder and was assumed to be included in the estimate of metabolism (cf. De Vlas 1979a).

Daily maintenance requirements (DMR): The DMR estimation was based on the relationships of daily maintenance with metabolic fish mass $\left(W^{0.8}\right)$ and temperature (Fonds et al. 1992). Fish mass for both plaice and flounder was determined using known speciesspecific length-mass relationships (Fonds et al. 1992):

$$
W=0.010503 L^{3}
$$

where $L$ is total length in $\mathrm{cm}$ and $W$ is wet mass in $\mathrm{g}$. The wet mass $\left(W_{i}\right)$ was estimated for each $0.5 \mathrm{~cm}$ length-based size class $\left(L_{i}\right)$ taking the mean length of the size class. Next, $W_{i}$ was converted into metabolic mass $\left(W_{i}^{0.8}\right)$ and multiplied by the number of individuals of each size class $\left(n_{i}\right)$ found per $\mathrm{m}^{2}$. Subsequently, the sum of $W_{i}^{0.8}$ for all size classes was calculated to obtain the total metabolic wet mass of the population per $\mathrm{m}^{2}\left(\sum n_{i} W_{i}^{0.8}\right)$. Finally, the daily food intake per $\mathrm{m}^{2}$ needed to meet daily maintenance requirements $\left(D M R ; g\right.$ AFDW $\mathrm{m}^{-2} \mathrm{~d}^{-1}$ ) was calculated according to the same formula as applied by De Vlas (1979a):

$$
D M R=0.17 \times 2^{0.1 T} \times 0.02 \sum_{i}\left(n_{i} W_{i}^{0.8}\right)
$$


where $T$ is temperature in ${ }^{\circ} \mathrm{C}, 2$ is the $Q_{10}$ (the increase in rate with a temperature increase of $10^{\circ} \mathrm{C}$ ), 0.02 is the maintenance coefficient $\left(W W^{-0.8} \mathrm{~d}^{-1}\right)$ and 0.17 is the conversion factor from wet mass to ash-free dry mass (De Vlas 1979a). The maintenance requirements of the plaice and flounder populations were estimated for each sampling day separately. This procedure was identical to the method used by De Vlas (1979a).

Daily growth requirements (DGR): The daily food intake required to accommodate for the observed growth was estimated as follows. First, for the different age groups of both plaice and flounder, the surveyspecific arithmetic mean length of all stations was estimated (see Zijlstra et al. 1982, van der Veer 1986). Next, Eq. (1) was applied to convert mean length per survey $j$ into mean wet mass per cruise $\left(W_{j}\right)$. The estimates of mean wet mass were used to determine the instantaneous growth rate $\left(G_{;} \mathrm{d}^{-1}\right)$ between 2 successive cruises as:

$$
G_{j \rightarrow j+1}=\frac{\ln W_{j+1}-\ln W_{j}}{t}
$$

where $W_{j}$ and $W_{j+1}$ are the mean wet mass at cruise $j$ and the subsequent cruise $j+1$, respectively, and $t$ is the time difference in days between the 2 cruises. $G$ was considered to represent the growth rate at the midpoint between 2 successive cruises. The various estimates of $G$ over time allowed fitting an exponential curve of $G$ as a function of time for each age group of both species. For 0-group fish, this relationship was determined for each year separately; for Iand II-group fish, all years were pooled together because of a lack of reliable estimates in some years. Based on these relationships, an estimate of $G$ at the various sampling dates was obtained for each age group of both species. The estimate of $G$ on sampling date $j$ was taken to represent growth of all size classes of an age group, and applied to determine daily growth in mass for each size class $\left(\Delta W_{j}\right)$. Daily population growth $\left(D P G ; g\right.$ wet mass $\left.\mathrm{d}^{-1}\right)$ on sampling date $j$ was calculated as the sum for all size classes $i$ of the product of daily growth multiplied by the number of individuals per $\mathrm{m}^{2}\left(n_{i}\right)$ :

$$
D P G_{j}=\sum_{\text {all } i} n_{i} \Delta W_{j}
$$

The amount of food needed for growth was calculated as 2 times the increase in wet mass (De Vlas 1979a) and therefore total population growth was multiplied by this net efficiency factor $(\times 2)$, and by 0.17 (conversion to AFDM, see De Vlas 1979a), resulting in an estimate of daily growth requirements per $\mathrm{m}^{2}$ on sampling date $j\left(D G R_{j} ; \mathrm{g}^{\mathrm{AFDM}} \mathrm{m}^{-2} \mathrm{~d}^{-1}\right)$ :

$$
D G R_{j}=0.17 \sum_{\text {all } i} 2 n_{i} \Delta W_{j}
$$

Total food intake: Daily food intake on sampling date $j\left(D F I_{j i}\right.$ g AFDM m $\left.{ }^{-2} \mathrm{~d}^{-1}\right)$ of the 0 , I- and II-group plaice and flounder populations was calculated as the sum of daily maintenance requirements $\left(D M R_{j}\right)$ and daily growth requirements $\left(D G R_{j}\right)$ of each age group:

$$
D F I_{j}=D M R_{j}+D G R_{j}
$$

Next, for 0-, I- and II-groups, total annual food intake was determined by first fitting a polynomial through the $D F I$, and solving the function by integration over the growing season (March-October).

Macrozoobenthic prey items. Since 1975, the Balgzand macrozoobenthos community has been consistently monitored quantitatively at 12 fixed transects of $1 \mathrm{~km}$ each distributed over the area, twice a year in late winter (mostly March) and late summer (mostly August). Details of sampling sites and methods can be found in earlier publications (e.g. Beukema \& Cadée 1997). In short, along each transect, cores to a depth of approximately $30 \mathrm{~cm}$ were taken at equal intervals $(20 \mathrm{~m})$, covering a total of $0.45 \mathrm{~m}^{2}$ in summer or $0.9 \mathrm{~m}^{2}$ in winter. All cores were sifted over a $1 \mathrm{~mm}$ sieve in the field and all macrozoobenthos retained were collected and sorted down to species level in the laboratory within a few days. For each species, numbers were counted, and the AFDM was determined by first drying for 2 to $3 \mathrm{~d}$ at $60^{\circ} \mathrm{C}$ in a ventilated stove, weighing and incinerating for $2 \mathrm{~h}$ at $520^{\circ} \mathrm{C}$. The weight loss after incineration was considered to represent AFDM. Bivalve species were split up in age groups based on external rings before AFDM was determined. For each transect, mean densities and biomass were estimated and the mean of all 12 transects was calculated. Only data for late summer were used in this paper.

Identification of potential prey items for juvenile flatfish was based on stomach content analyses performed in 1976 and 1977 by De Vlas (1979a), combined with unpublished data from 2 other periods, 1986 and 2008 to 2010 , to verify whether shifts in diet had occurred over time, in particular, related to increasing abundances of invasive macrobenthic species.

\section{RESULTS}

\section{Flatfish abundance}

The NIOZ fyke net catches showed that, from approximately 1980 onwards, I- and II-group plaice densities started to decrease, and within 10 yr they had reached zero. Young-of-the-year plaice (0-group) were present during the whole period, but numbers also decreased from the mid-1980s onwards, and stabilized at low numbers from 2000 onwards (Fig. 2a). For flounder, the differences between age classes were less 


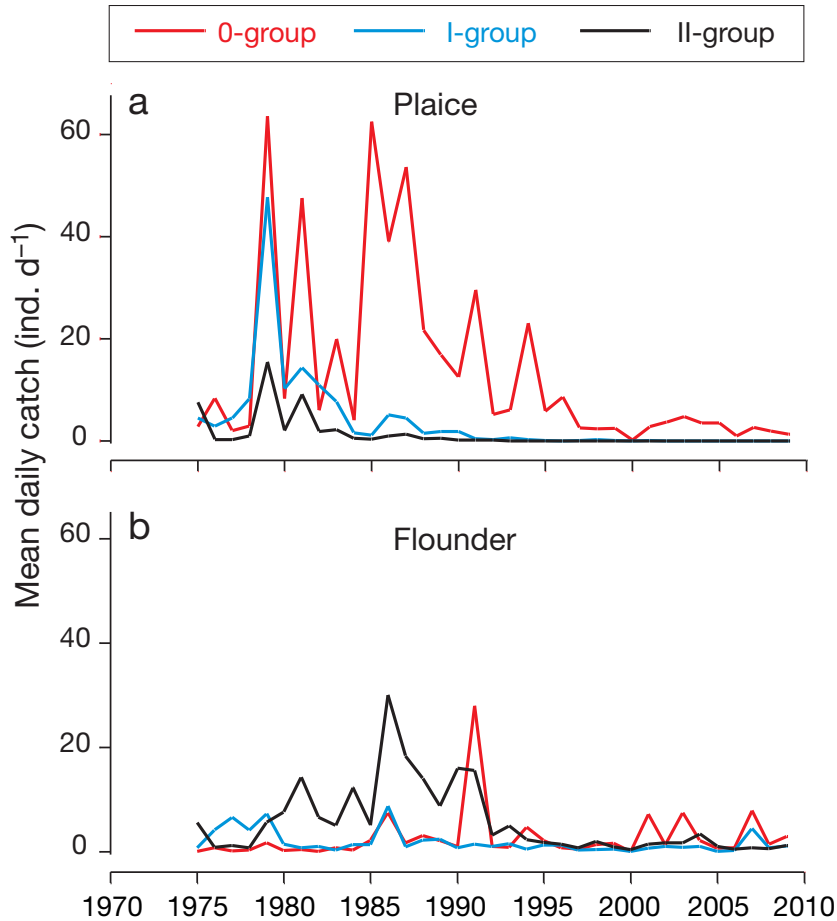

Fig. 2. Pleuronectes platessa and Platichthys flesus. Mean daily catch of the NIOZ fyke net in the western Dutch Wadden Sea in autumn for (a) juvenile plaice and (b) juvenile flounder

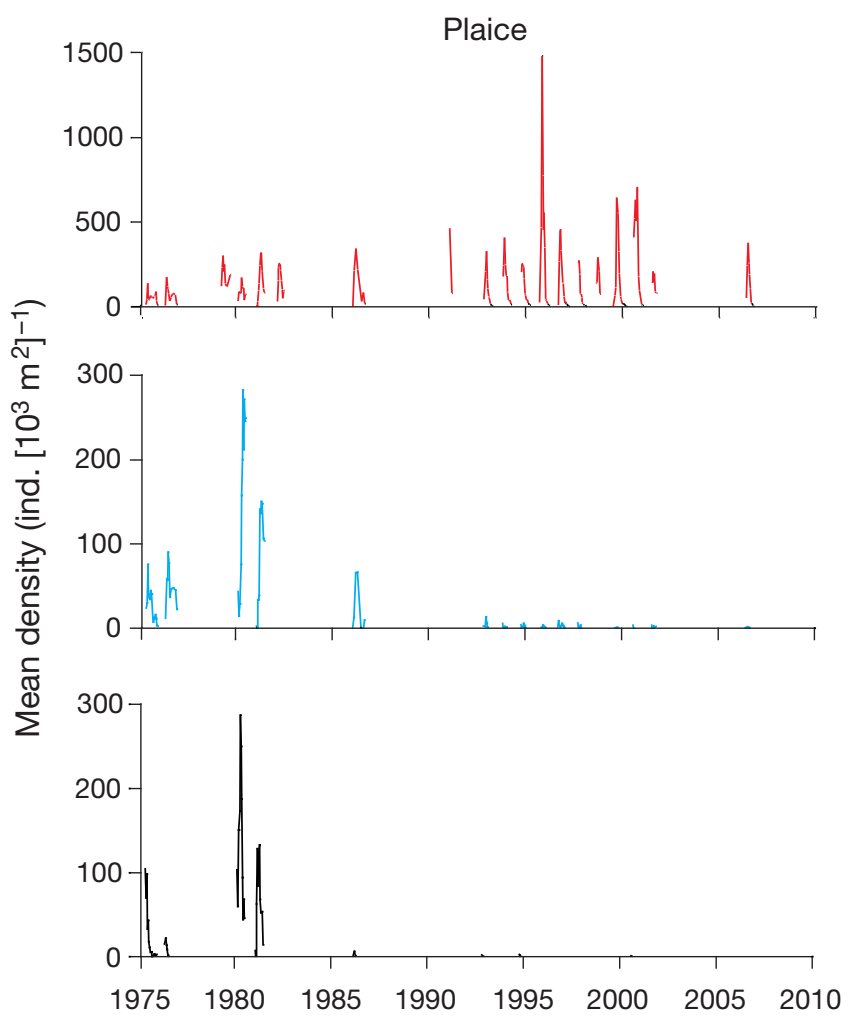

clear (Fig. 2b). Densities were on average lower than those of plaice and approached zero during a period in the late 1990s. In recent years, densities have increased, but they are still lower than in the past.

The abundance of juvenile plaice and flounder at the Balgzand intertidal during high water roughly showed a similar pattern over time as the fyke net catches (Fig. 3). 0-group plaice and flounder were present during all years of fishing; however, from the late 1980s onwards, no I- or II-group plaice were found in the area. I- and II-group flounder were still present, but in very low numbers. The seasonal pattern over time also changed, especially in plaice. In the 1970s, juvenile plaice were present from early spring until the end of October; however, from the mid-1980s, 0-group plaice (the only remaining age group) had already disappeared from the intertidal in July-August (data not shown). Overall, densities of flounder were approximately a factor of 10 lower than those of plaice.

\section{Predation pressure}

Total annual food intake was estimated in all years of sampling except for 1983, 1991, 1999 and 2002, when there were less than 3 cruises (1983 and 1991) or when cruises were only executed in the first part of the sea-
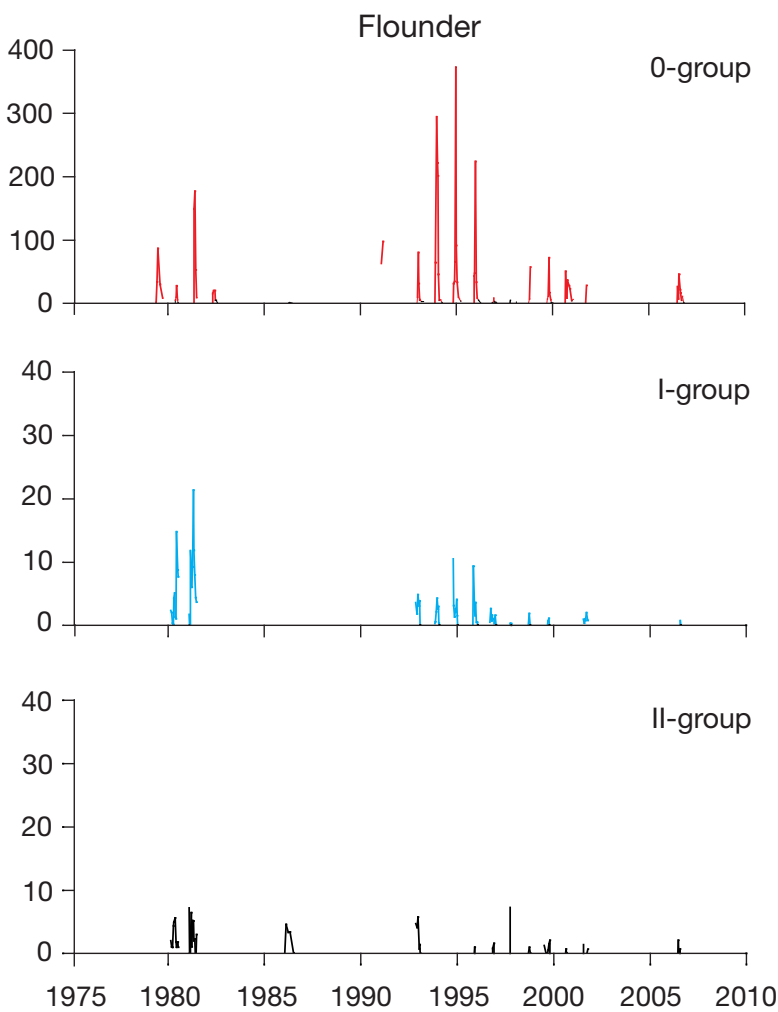

Fig. 3. Pleuronectes platessa and Platichthys flesus. Mean density of juvenile plaice and flounder at Balgzand intertidal during high water 


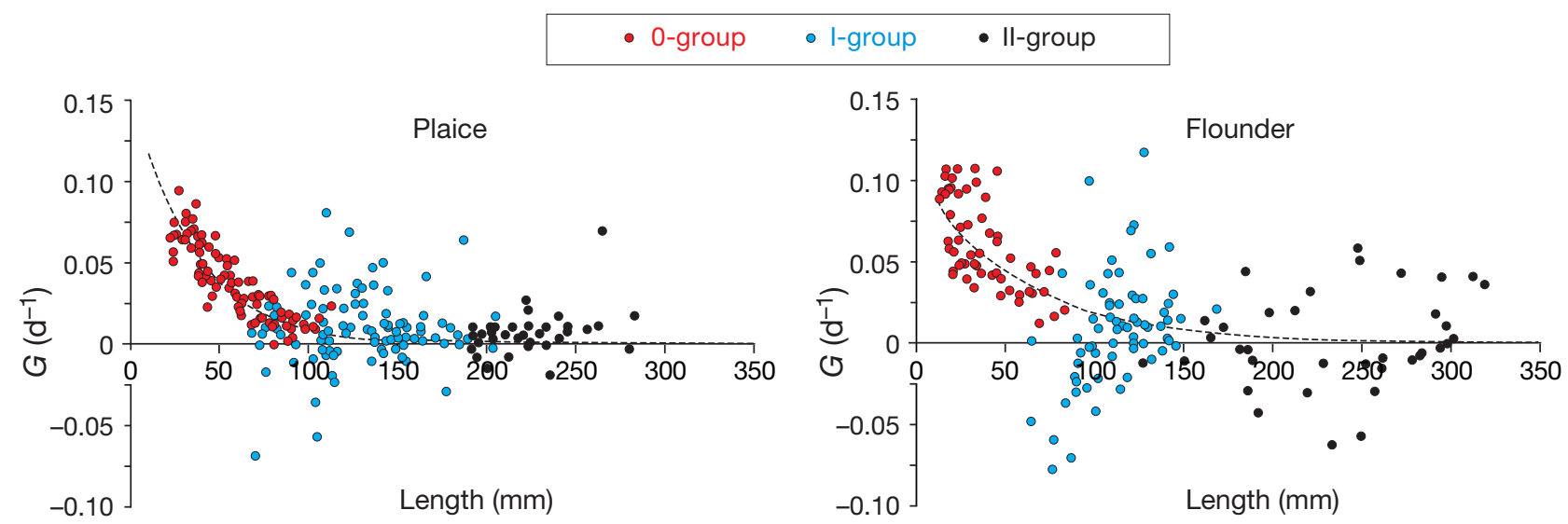

Fig. 4. Pleuronectes platessa and Platichthys flesus. Instantaneous growth rate of juvenile plaice and flounder after peak settlement at Balgzand intertidal in relation to fish size. All years combined

son (1999 and 2002). In the years 1979 and 1982, only 0-group plaice and flounder were sampled; therefore, food intake was not estimated for I- and II-group, although they were present.

For both plaice and flounder, the instantaneous growth rate decreased during the juvenile stage from approximately $0.10 \mathrm{~d}^{-1}$ in 0 -group to almost zero in II- group (Fig. 4). This was reflected in the energy flux into growth, which decreased from almost $80 \%$ in justsettled flatfish to zero in II-group fish at the end of their third growing season (Fig. 5). The increase in the energy flux into growth at the beginning of the growing season of I- and II- group fish compared with that of similar sized fish at the end of the previous sea-

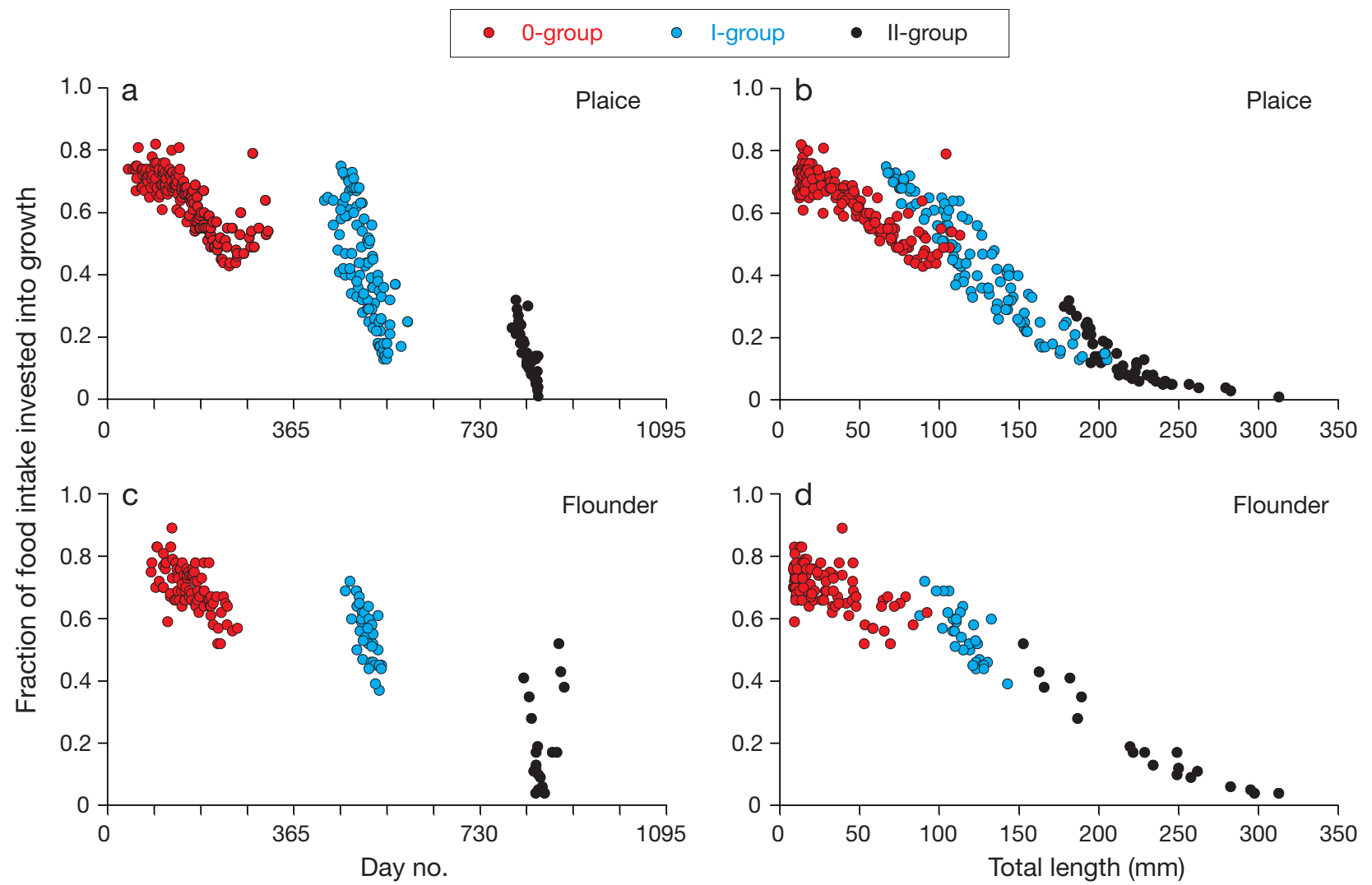

Fig. 5. Pleuronectes platessa and Platichthys flesus. Fraction of food intake invested into growth in juvenile plaice (a,b) and flounder $(\mathrm{c}, \mathrm{d})$ in relation to day number $(\mathrm{a}, \mathrm{c})$ and fish length $(\mathrm{b}, \mathrm{d})$ after peak settlement at Balgzand intertidal. All years combined 


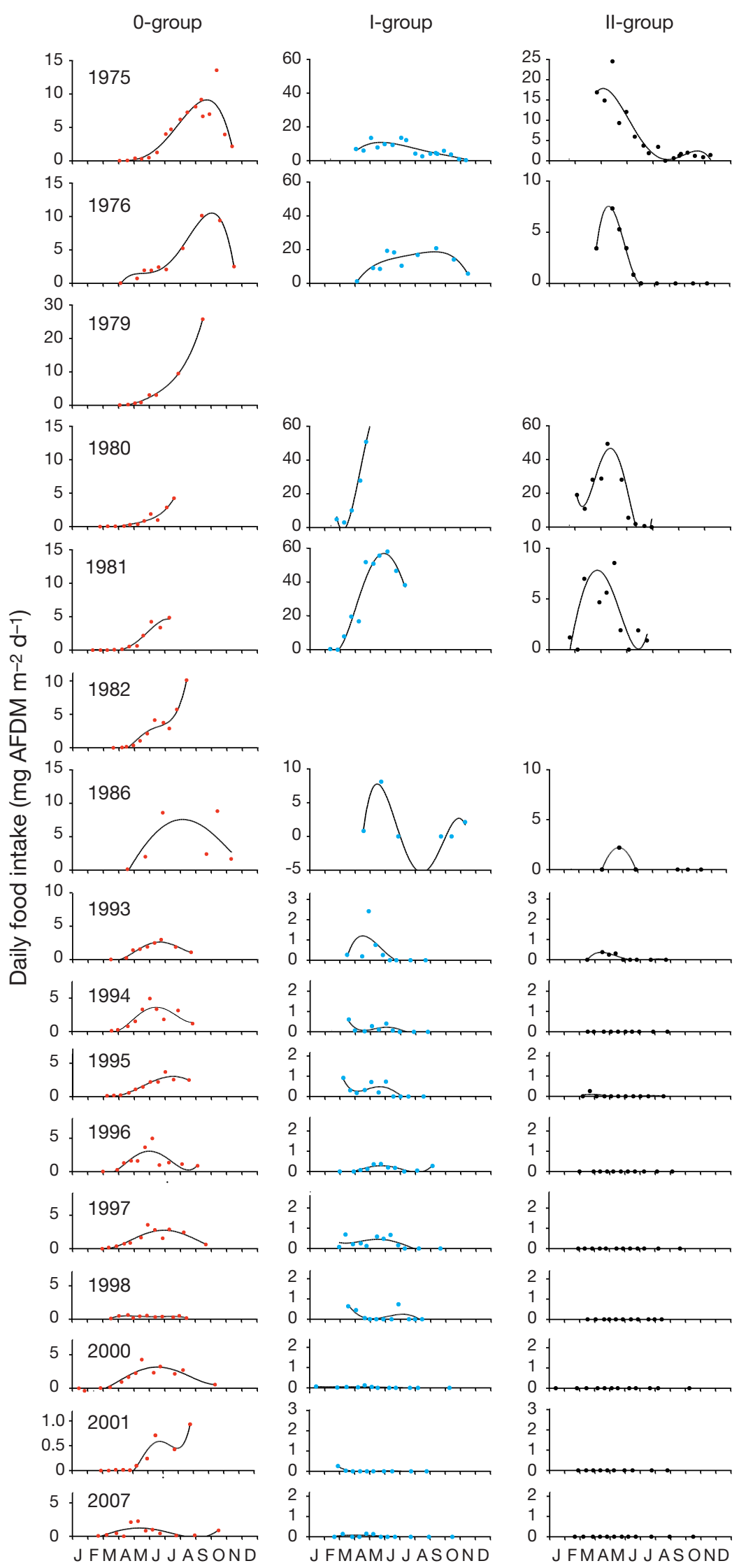

son reflected the lower temperature and, hence, lower maintenance requirements at the beginning of the season.

For each species, per year and age group, food intake was estimated by means of fourth-order polynomials (Figs. 6 \& 7). In some cases, third- or second-order polynomials were sufficient. In some years, the growing season (March-October) was not sampled completely, resulting in a slight underestimation of annual predation pressure. Predation pressure by juvenile plaice far exceeded that of juvenile flounder. Over the period 1975 to 2007, annual predation pressure of both species decreased from around 4 to $6 \mathrm{~g}$ AFDM m $\mathrm{m}^{-2} \mathrm{yr}^{-1}$ in the late 1970s to $1.5 \mathrm{~g} \mathrm{AFDM} \mathrm{m}^{-2} \mathrm{yr}^{-1}$ in 1986 and to less than $0.25 \mathrm{~g} \mathrm{AFDM} \mathrm{m}^{-2} \mathrm{yr}^{-1}$ from 1993 onwards (Fig. 8). The decrease was mainly caused by the disappearance of II- and Igroup plaice over time and, to a lesser extent, by the shorter growing season of 0group plaice at Balgzand from the mid1980s onwards (Table 1).

\section{Macrozoobenthic prey items}

Macrozoobenthic biomass in late summer at Balgzand showed a steady increase from $\sim 20$ in 1975 to $80 \mathrm{~g}^{\mathrm{AFDM} \mathrm{m}}{ }^{-2}$ in 2009 (Fig. 9a). Most of the biomass increase was due to the contribution of large bivalves such as Mya arenaria and Crassostrea gigas (data not shown).

Potential prey items for juvenile plaice and flounder consisted of intact specimens and parts of individuals (Table 1 in De Vlas 1979a). Body parts were found to consist mainly of siphon tips in bivalves, tail tips from the polychaetes Arenicola marina and Heteromastus filiformis, and heads and tentacles of Pygospio elegans. The group of whole individuals was formed by various juvenile bivalves except Mytilus edulis and a variety of polychaete species excluding $A$. marina. Differences in diet between juvenile plaice and flounder were small and mainly consisted of the relative contribution

Fig. 6. Pleuronectes platessa. Daily food intake of juvenile plaice at Balgzand intertidal during the various years of observations. Polynomial functions (maximum fourth-order) were fitted through the data points 


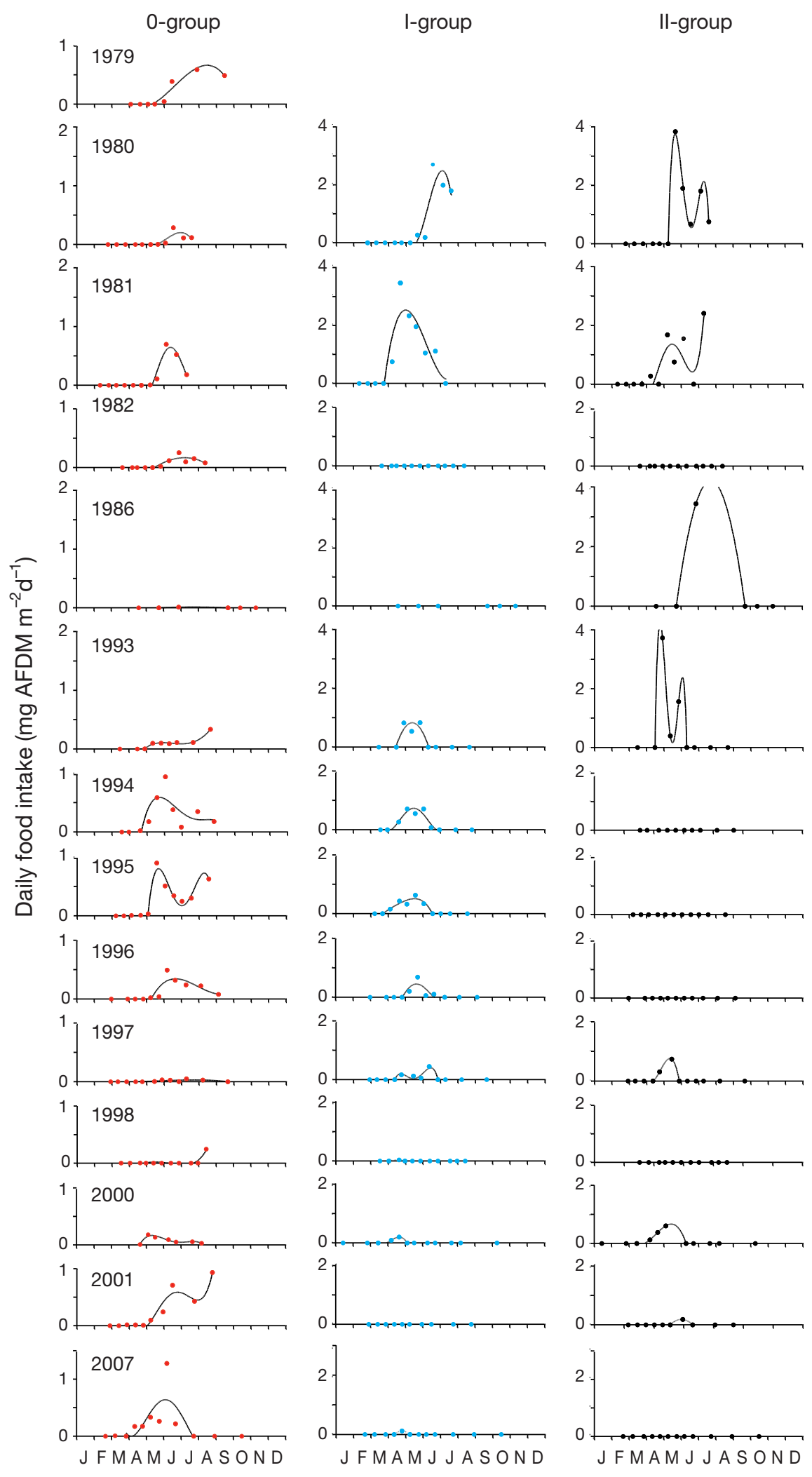

Fig. 7. Platichthys flesus. Daily food intake of juvenile flounder at Balgzand intertidal during the various years of observations. Polynomial functions (maximum fourth-order) were fitted through the data points of the various prey items. Compared with juvenile plaice, the diet of flounder contained fewer body parts. Diet composition in 1986 and in 2008 to 2010 showed a similar pattern as in 1976 (data not shown). In addition, juveniles of the American razor clam Ensis directus were part of the diet in 1986 and 2008 to 2010 while the spionid polychaete Marenzelleria viridis was prey in 2008 to 2010. Stomach content data from the NIOZ fyke net programme showed that E. directus appeared in the stomachs from the late 1970 s onwards and $M$. viridis appeared from the late 1980s (J. IJ. Witte unpubl. data). A summary of the main potential prey items for juvenile plaice and flounder is presented in Table 2 .

The biomass of potential prey items of juvenile flatfish showed an increase over time, from $\sim 10 \mathrm{~g}$ AFDM m ${ }^{-2}$ in 1975 to a maximum of $30 \mathrm{~g} \mathrm{AFDM} \mathrm{m}^{-2}$ in 2005, mainly consisting of polychaetes. In recent years, biomasses dropped back to a level of $\sim 10 \mathrm{~g}$ AFDM m ${ }^{-2}$ (Fig. 9b).

\section{DISCUSSION}

The accuracy of annual predation pressure by juvenile plaice and flounder estimates relies to a large extent on the abundance estimates. Despite species-specific corrections for trawl and mesh efficiency (Kuipers 1975, Dapper 1978), variability in abundance estimates is substantial, on the order of $35 \%$ as revealed for plaice (Zijlstra et al. 1982). This means that, in analysing trends over time, an interannual variability of more than $35 \%$ should be taken into account. However, the observed changes, with a complete loss of especially II- and Igroup plaice, are much larger. For juvenile flounder with a more patchy distribution in the silty areas of the Balgzand (van der Veer et al. 1991), this variability might be even higher, but because the abundance of juvenile flounder at Balgzand is an order of magnitude lower than that of juvenile 


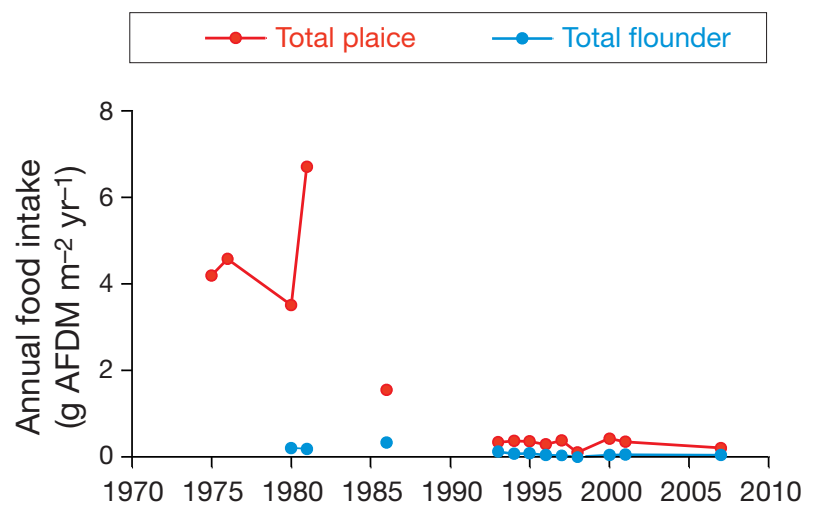

Fig. 8. Pleuronectes platessa and Platichthys flesus. Annual food intake of juvenile plaice and flounder at Balgzand intertidal at high water during the period $1975-2007$

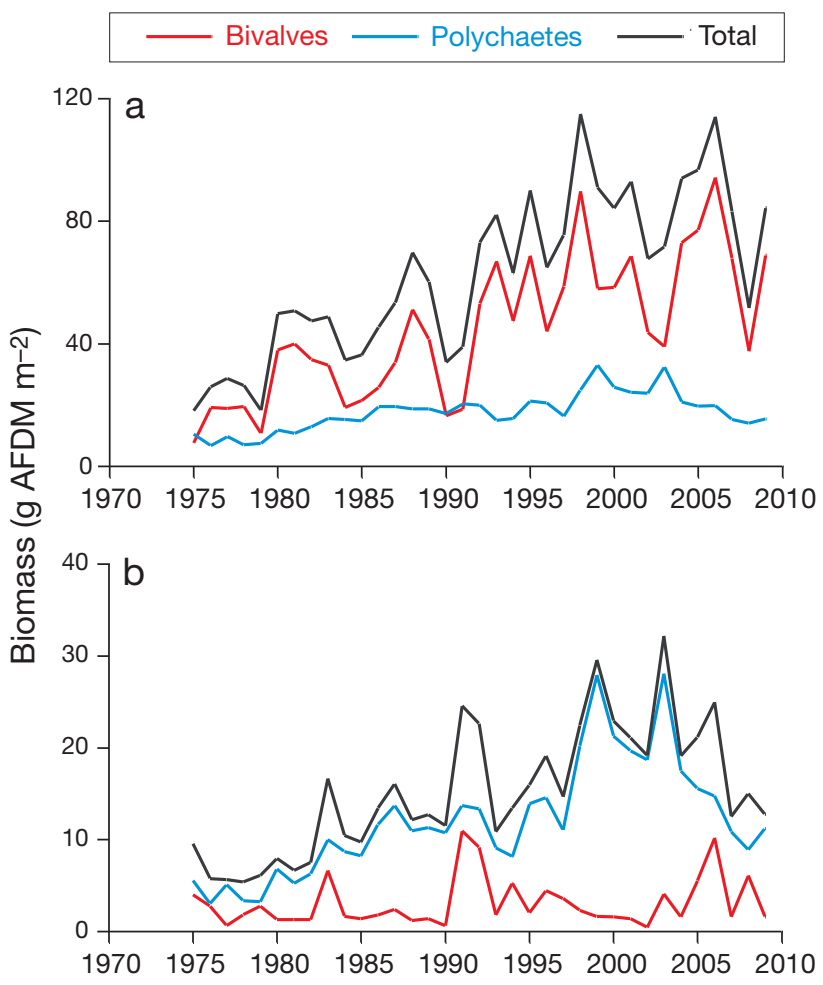

Fig. 9. Biomass of total macrozoobenthos (a) and potential food items for juvenile flatfish (b) at the Balgzand intertidal between 1975 and 2009

plaice, it will hardly affect the overall estimate of predation pressure of juvenile flatfish at Balgzand.

To allow for a direct comparison over time, the methods applied by De Vlas (1979a) were also followed in this study. The estimation of maintenance requirements was taken directly from De Vlas (1979a). For the contribution of growth, a slightly modified approach was followed: shifts in size-frequency distributions were used to derive a relationship between instantaneous population growth rate $G\left(\mathrm{~d}^{-1}\right)$ over time and,
Table 1. Pleuronectes platessa and Platichthys flesus. Annual predation pressure ( $\mathrm{g}$ AFDM m $\mathrm{m}^{-2} \mathrm{yr}^{-1}$ ) by juvenile plaice and flounder at the Balgzand intertidal in various years over the period 1975-2007, based on ingestion estimates

\begin{tabular}{|cccc|}
\hline Year & $\begin{array}{c}\text { Predation by } \\
\text { juvenile plaice }\end{array}$ & $\begin{array}{c}\text { Predation by } \\
\text { juvenile flounder }\end{array}$ & $\begin{array}{c}\text { Total predation } \\
\text { pressure }\end{array}$ \\
\hline 1975 & 4.2 & & $>4.2$ \\
1976 & 4.6 & & $>4.6$ \\
1980 & 3.5 & 0.2 & 3.7 \\
1981 & 6.7 & 0.2 & 6.9 \\
1986 & 1.5 & 0.3 & 1.9 \\
1993 & 0.3 & 0.2 & 0.5 \\
1994 & 0.4 & 0.1 & 0.5 \\
1995 & 0.4 & 0.1 & 0.5 \\
1996 & 0.3 & 0.04 & 0.3 \\
1997 & 0.4 & 0.04 & 0.4 \\
1998 & 0.1 & 0.01 & 0.1 \\
2000 & 0.4 & 0.04 & 0.4 \\
2001 & 0.3 & 0.05 & 0.4 \\
2007 & 0.2 & 0.04 & 0.3 \\
\hline
\end{tabular}

Table 2. Pleuronectes platessa and Platichthys flesus. Potential macrozoobenthic food items of juvenile plaice and flounder at the Balgzand intertidal over the period 1975-2010, based on stomach content analysis

\begin{tabular}{|c|c|c|}
\hline Prey species & Items eaten & Biomass \\
\hline \multicolumn{3}{|l|}{ Bivalves } \\
\hline $\begin{array}{l}\text { Juvenile } \\
\text { spat }\end{array}$ & $\begin{array}{l}\text { Whole individuals } \\
\text { except Mytilus edulis }\end{array}$ & $\begin{array}{l}\text { Total biomass } \\
\text { except } M \text {. edulis }\end{array}$ \\
\hline Adults & $\begin{array}{l}\text { Only siphon tips } \\
\text { except } M \text {. edulis }\end{array}$ & $\begin{array}{l}3 \% \text { of total biomass } \\
\text { except } M . \text { edulis } \\
\text { (De Vlas 1985) }\end{array}$ \\
\hline \multicolumn{3}{|l|}{ Polychaetes } \\
\hline $\begin{array}{l}\text { Arenicola } \\
\text { marina }\end{array}$ & Only tail tips & $\begin{array}{l}15 \% \text { of total biomass } \\
\text { (De Vlas 1979b) }\end{array}$ \\
\hline $\begin{array}{l}\text { All other } \\
\text { polychaetes }\end{array}$ & $\begin{array}{l}\text { Parts and whole } \\
\text { individuals }\end{array}$ & Total biomass \\
\hline
\end{tabular}

subsequently, this relationship was used to estimate $G$ at each day of sampling. This method is more elegant and will hardly affect the resulting patterns: the estimate for plaice in 1975 in the present study for the whole Balgzand was in the same order of magnitude as the estimate by De Vlas (1979a) for the eastern part. The implicit assumption in the estimates by De Vlas (1979a) is that there are no losses associated with ingestion and thus ingestion is equal to the estimate of required energy for maintenance and growth (assimilation). For comparison purposes, the same approach has been followed in this paper, although in general, losses owing to ingestion are considered to be on the order of $20 \%$ (Brett \& Groves 1979, van der Veer et al. 2009). Consequently, the estimates by De Vlas (1979a) and those in this paper might be underestimates. 


\section{Trends in juvenile flatfish abundance}

Since the first reports of worldwide depletion of fish communities (Pauly et al. 1998, Myers \& Worm 2003), it has become clear that these phenomena also occur on a smaller scale, such as in the highly productive North Sea; long-term trawl surveys show, for instance, that the absolute abundance of large fish has decreased and that of small fish has steadily and significantly increased during the last decades (Daan et al. 2005). Also, in the coastal zone of the North Sea, in the Dutch Wadden Sea, demersal fish biomass and abundance have shown a decreasing trend after the 1980s (Tulp et al. 2008).

The Wadden Sea is considered to be an important nursery area for various fish species, including plaice and sole (Zijlstra 1972), especially in the intertidal and the shallow subtidal ( $<5 \mathrm{~m}$ at low water) (Zijlstra et al. 1982). The present study shows that in a large intertidal area, the Balgzand, the abundance of juvenile plaice and flounder has changed substantially over time: 3 year classes (0-, I- and II-group) were present until the 1980s, after which densities of I- and II-group plaice and flounder dropped to levels close to zero. The decrease in the abundance of I- and IIgroup plaice and flounder in the western Wadden Sea is in line with the observations of a shift of larger plaice $(20-39 \mathrm{~cm})$ towards deeper water in the coastal zone of the North Sea before the 1990s (van Keeken et al. 2007). Since the 1990s, the abundance of 0 -group flatfish, especially plaice, also decreased in the Wadden Sea in autumn, which might reflect an earlier emigration of 0 -group flatfish to offshore. Based on long-term trends from a demersal fish survey, this pattern appears to apply for at least the whole Dutch Wadden Sea (Tulp et al. 2008). For the Balgzand intertidal, this suggests that the nursery function of the area has changed dramatically: from a system functioning as a suitable area for 0-, I- and IIgroup flatfish, it has become a nursery area for justsettling 0-group flatfish only.

The underlying mechanism for these shifts is unclear. The lack of I- and II-group flatfish suggests that juvenile I- and II-group plaice no longer re-immigrate from offshore into the intertidal in spring. The fact that here does not seem to be a consistent decreasingtrend in plaice recruitment (Anonymous 2006) suggests that overall mortality during the juvenile stage has not changed. A shift towards deeper water caused by increased inshore predation by cormorants and seals (Leopold et al. 1998) therefore seems unlikely. In addition, the possibility that increased water temperatures might have exceeded the maximum tolerance range (cf. van Keeken et al. 2007) is questionable. In that case, all I- and II-group flounder with a temperature tolerance similar to plaice (Freitas et al. 2010) would have also disappeared. However, larger flounder are still present in the area, although in low numbers. Furthermore, densities of II- and Igroup plaice had already decreased before warming of the area began around 1985 (van Aken 2008), and so far, higher temperatures observed since 1989 have even had a slightly positive effect on growth of 0 group plaice (Teal et al. 2008). The analysis of growth versus maintenance requirements in this study indicates that, in both plaice and flounder, the energy available for growth decreases over time, reaching zero at the end of the third year of life. It might explain why, in the past, II-group plaice did not return in the following spring as III-group in the Wadden Sea (Kuipers 1977).

A recent analysis for 0-group plaice has shown that, during the growing season, food conditions decrease from optimal to suboptimal (van der Veer et al. 2010), thereby directly affecting and reducing the amount of energy available for growth. No information is available about the food conditions for flounder and I- and II-group plaice. If, for these groups, food conditions are also suboptimal in summer, it reduces the growth window for juvenile flatfish in the area. However, the analysis in the present study shows that this pattern has not changed since the 1970s, which is also supported by the fact that the biomass of potential prey items has not decreased. Another possibility, reduced immigration of I- and IIgroup flatfish because of a decrease in competition with larger plaice offshore (van Keeken et al. 2007), cannot be excluded. Regime shifts have been observed in the area in 1979 and 1988 (Weijerman et al. 2005). These have affected the system via shifts in a number of environmental factors, but it seems unlikely that there is any bottom-up control or a relationship with the abundance patterns observed in juvenile flatfish in the area.

Overall, the absence of I- and II-group flatfish in the intertidal cannot be explained at present; however, processes operating offshore are most likely involved.

\section{Top-down effects of flatfish predation}

The fact that macrobenthic biomass in temperate estuaries can be predicted from primary production data (Herman et al. 1999) suggests a bottom-up (resource-driven) control in these systems. Top-down effects of predation on whole individuals in such a bottom-up controlled system would be restricted to species composition and abundance. The stomach content analyses illustrate the wide prey field of both species. In addition, new invasive species such as the American 
razor clam Ensis directus and the spionid polychaete Marenzelleria viridis appear in the diet of both flatfish species after some time. In the 1970s, predation pressure was around 4 to $6 \mathrm{~g} \mathrm{AFDM} \mathrm{m}{ }^{-2}$, which would be substantial enough to induce a top-down effect. However, this was not described at that time. In recent years, predation pressure seems to be too low to be exerting direct top-down effect.

Indirect top-down effects by predation are more likely, especially those related to the consumption of regenerating body parts. The cropping of tail tips of the lugworm Arenicola marina results in a loss of posterior segments and hence a reduction of the overall life span (De Vlas 1979b). At a frequency of amputation of once a week, growth and reproductive output also decreased (Bergman et al. 1988). Flatfish also heavily prey upon siphon tips of various bivalves (De Vlas 1979a). In some species, such as the Baltic clam Macoma balthica, siphon nipping by juvenile flatfish forces the bivalves to burry shallower in the sediment, thereby becoming within the reach of probing waders (De Vlas 1985, Zwarts 1996, De Goeij et al. 2001). In this way, siphon nipping by juvenile flatfishes facilitates predation by other top predators. In the 1970s, predation by juvenile flatfish at Balgzand might have been high enough to result in top-down effects in the form of facilitation for waders via siphon nipping. In recent time, this predation pressure has dropped to a level of approximately $0.25 \mathrm{~g} \mathrm{AFDM} \mathrm{m}^{-2}$. At the same time, potential food abundance for juvenile plaice and flounder at Balgzand has not changed and total benthic biomass has increased substantially. To what extent this increase reflects the effect of a predation pressure release is unclear.

Although the sampling data do not cover the whole time period 1975 to 2009, results indicate that topdown predation by juvenile flatfish has decreased more or less gradually over time. In parallel, the nursery function of the Balgzand intertidal has degraded and it seems likely that this will also hold true for other intertidal areas. Besides the intertidal, the coastal zone and the subtidal are important flatfish nursery areas (Zijlstra 1972, van der Veer \& Witte 1993). The trends in flatfish abundance in the Wadden Sea area (Tulp et al. 2008) suggest that the nursery function of subtidal areas has degraded as well. Data on different intertidal and subtidal nursery areas over time would offer the opportunity to apply McCall's theoretical basin model (McCall 1990) to test whether the degradation occurred in all areas simultaneously or whether marginal nurseries were vacated first.

Acknowledgements. Thanks are due to all those colleagues and students who participated in the Balgzand high-water programme over the years. Special thanks are due to B.
Kuipers and the late J. Zijlstra who initiated the programme, to R. Dapper for his continuous support either in the field or in the laboratory and to the skippers of the NIOZ RV 'Griend' and 'Stern' over the years, E. Adriaans and the late C. Sneijders and S. Dogger. Figures were prepared by H. Hobbelink. These investigations were in part supported by the Netherlands Organization for Scientific Research (NWO) via Project 839.08.241 of the National programme Sea and Coastal Research (ZKO).

\section{LITERATURE CITED}

- Amara R, Laffargue P, Dewarumez JM, Maryniak C, Lagardère $F$, Luczac $C$ (2001) Feeding ecology and growth of 0-group flatfish (sole, dab and plaice) on a nursery ground (Southern Bight of the North Sea). J Fish Biol 58:788-803

Anonymous (2006) Report of the Working Group on the assessment of demersal stocks in the North Sea and Skagerrak (WGNSSK). 5-14 September 2006, ICES, Copenhagen. ACFM:35

Ansell AD, Comely CA, Robb L (1999) Distribution, movements and diet of macrocrustaceans on a Scottish sandy beach with particular reference to predation on juvenile fishes. Mar Ecol Prog Ser 176:115-130

- Bergman MJN, van der Veer HW, Karczmarski L (1988) Impact of tail nipping on mortality, growth and reproduction of Arenicola marina. Neth J Sea Res 22:83-90

Beukema JJ, Cadée GC (1997) Local differences in macrozoobenthic response to enhanced food supply caused by mild eutrophication in a Wadden Sea area: food is only locally a limiting factor. Limnol Oceanogr 42:1424-1435

Bolle LJ, Dapper R, Witte JIJ, van der Veer HW (1994) Nursery grounds of dab (Limanda limanda L.) in the southern North Sea. Neth J Sea Res 32:299-307

Brett JR, Groves TDD (1979) Physiological energetics. In: Hoar WS, Randall DJ, Brett JR (eds) Fish physiology. Bioenergetics and growth, Vol 8. Academic Press, New York, p. 279-352

$>$ Daan N, Gislason H, Pope JG, Rice JC (2005) Changes in the north Sea fish community: Evidence of indirect effects of fishing? ICES J Mar Sci 62:177-188

Dapper R (1978) De Balgzand scholgegevens 1975, 1976, 1977. Interne Verslagen Nederlands Instituut voor Onderzoek der Zee, Texel, p. 1-53

> De Goeij P, Luttikhuizen PC, van der Meer J, Piersma T (2001) Facilitation on an intertidal mudflat: the effect of siphon nipping by flatfish on burying depth of the bivalve Macoma balthica. Oecologia 126:500-506

De Vlas J (1979a) Annual food intake by plaice and flounder in a tidal flat area in the Dutch Wadden sea, with special reference to consumption of regenerating parts of macrobenthic prey. Neth J Sea Res 13:117-153

De Vlas (1979b) Secondary production by tail regeneration in a tidal flat population of lugworms (Arenicola marina), cropped by flatfish. Neth J Sea Res 13:362-393

De Vlas J (1985) Secondary production by siphon regeneration in a tidal flat population of Macoma balthica. Neth J Sea Res 19:147-164

> Fonds M, Cronie R, Vethaak AD, van der Puyl P (1992) Metabolism, food consumption and growth of plaice (Pleuronectes platessa) and flounder (Platichthys flesus) in relation to fish size and temperature. Neth J Sea Res 29: $127-143$

- Freitas V, Bailey KM, van der Veer HW (2008) Population regulation of epibenthic species in coastal ecosystems, with 
implications for latitudinal patterns. J Sea Res 60:105-116 Freitas V, Cardoso JFMF, Lika K, Peck MA, Campos J, Kooijman SALM, van der Veer HW (2010) Analysis of physiological performance of North Atlantic marine organisms by means of interspecies differences in DEB parameters. Philos Trans R Soc Lond B 365:3553-3565

Goodall DW (1983) Estuaries and enclosed seas. Ecosystems of the world, Vol 26. Elsevier, Amsterdam

Herman PMJ, Middelburg JJ, van de Koppel J, Heip CHR (1999) Ecology of estuarine macrobenthos. Adv Ecol Res 29:195-240

Kuipers B (1975) On the efficiency of a two-metre beam trawl for juvenile plaice (Pleuronectes platessa). Neth J Sea Res 9:69-85

Kuipers BR (1977) On the ecology of juvenile plaice on a tidal flat in the Wadden Sea. Neth J Sea Res 11:56-91

Kuipers BR, de Wilde PAWJ, Creutzberg F (1981) Energy flow in a tidal ecosystem. Mar Ecol Prog Ser 5:215-221

Leopold MF, van Damme CJG, van der Veer HW (1998) Diet of cormorants and the impact of cormorant predation on juvenile flatfish in the Dutch Wadden Sea. J Sea Res 40:93-107

MacCall AD (1990) Dynamic geography of marine fish populations. University of Washington Press, Seattle, WA

McLusky DS (1989) The estuarine ecosystem, 2nd edn. Blackie, Glasgow

Meire PM, Seys J, Buijs J, Coosen J (1994) Spatial and temporal patterns of intertidal macrobenthic populations in the Oosterschelde: Are they influenced by the construction of the storm-surge barrier? Hydrobiologia 282-283:157-182

Myers RA, Worm B (2003) Rapid worldwide depletion of predatory fish communities. Nature 423:280-283

Nédélec C (1982) Definition and classification of fishing gear categories. FAO Fish Tech Pap No. 222. FAO, Rome

Pauly D, Christensen V, Dalsgaard J, Froesse R, Torres F (1998) Fishing down marine food webs. Science 279:860-863

Pihl L (1985) Food selection and consumption of mobile epibenthic fauna in shallow marine areas. Mar Ecol Prog Ser 22:169-179

Rijnsdorp AD, Vingerhoed B (2001) Feeding of plaice Pleuronectes platessa L. and sole Solea solea (L.) in relation to the effects of bottom trawling. J Sea Res 45:219-229

Riley JD, Corlett J (1966) The numbers of 0-group plaice in Port Erin Bay 1964-66. Annu Rep Mar Biol Stn Port Erin 78:51-56

Summers RW (1980) The diet and feeding behaviour of the flounder Platichthys flesus (L.) in the Ythan estuary, Aberdeenshire, Scotland. Estuar Coast Mar Sci 11: $217-228$

Teal LR, De Leeuw JJ, Rijnsdorp AD, van der Veer HW (2008) Effects of climate change on growth of 0-group sole and plaice. Mar Ecol Prog Ser 358:219-230

Tulp I, Bolle LJ, Rijnsdorp AD (2008) Signals from the shallows: in search of common patterns in long-term trends in Dutch estuarine and coastal fish. J Sea Res 60:54-73

Editorial responsibility: Stylianos Somarakis,

Heraklion, Greece van Aken HM (2008) Variability of the water temperature in the western Wadden Sea on tidal to centennial time scales. J Sea Res 60:227-234

van der Veer HW (1986) Immigration, settlement, and density-dependent mortality of a larval and early postlarval 0group plaice (Pleuronectes platessa) population in the western Wadden Sea. Mar Ecol Prog Ser 29:223-236

van der Veer HW, Witte JIJ (1993) The 'maximum growth/ optimal food condition' hypothesis: a test for 0-group plaice Pleuronectes platessa in the Dutch Wadden Sea. Mar Ecol Prog Ser 101:81-90

van der Veer HW, Witte JIJ (1999) Year-class strength of plaice Pleuronectes platessa L. in the Southern Bight of the North Sea: a validation and analysis of the inverse relationship with winter seawater temperature. Mar Ecol Prog Ser 184:245-257

van der Veer HW, Bergman MJN, Dapper R, Witte JIJ (1991) Population dynamics of an intertidal 0-group flounder Platichthys flesus population in the western Dutch Wadden Sea. Mar Ecol Prog Ser 73:141-148

van der Veer HW, Witte JIJ, Beumkes HA, Dapper R, Jongejan WP, van der Meer J (1992) Intertidal fish traps as a tool to study long-term trends in juvenile flatfish populations. Neth J Sea Res 29:119-126

van der Veer HW, Dapper R, Witte JIJ (2001) The nursery function of the intertidal areas in the western Wadden Sea for 0-group sole Solea solea (L.). J Sea Res 45:271-279

van der Veer HW, Cardoso JFMF, Peck MA, Kooijman SALM (2009) Physiological performance of plaice Pleuronectes platessa (L.): a comparison of static and dynamic energy budgets. J Sea Res 62:83-92

> van der Veer HW, Freitas V, Koot J, Witte JIJ, Zuur AF (2010) Food limitation in epibenthic species in temperate intertidal systems in summer: analysis of 0-group plaice Pleuronectes platessa. Mar Ecol Prog Ser 416:215-227

> van Keeken OA, van Hoppe M, Grift RE, Rijnsdorp AD (2007) Changes in the spatial distribution of North Sea plaice (Pleuronectes platessa) and implications for fisheries management. J Sea Res 57:187-197

Weijerman M, Lindeboom HJ, Zuur AF (2005) Regime shifts in marine ecosystems of the North Sea and Wadden Sea. Mar Ecol Prog Ser 298:21-39

Zijlstra JJ (1972) On the importance of the Wadden Sea as a nursery area in relation to the conservation of the southern North Sea fishery resources. Symp Zool Soc Lond 29: 233-258

Zijlstra JJ, Dapper R, Witte JIJ (1982) Settlement, growth and mortality of post-larval plaice (Pleuronectes platessa) in the western Wadden Sea. Neth J Sea Res 15:250-272

Zwarts L (1996) Waders and their estuarine food supplies. $\mathrm{PhD}$ thesis, Rijksuniversiteit Groningen, Groningen

> Zwarts L, Blomert AM, Wanink JH (1992) Annual and seasonal variation in the food supply harvestable by knot Calidris canutus staging in the Wadden Sea in late summer. Mar Ecol Prog Ser 83:129-139

Submitted: February 1, 2011; Accepted: May 12, 2011 Proofs received from author(s): July 11, 2011 